
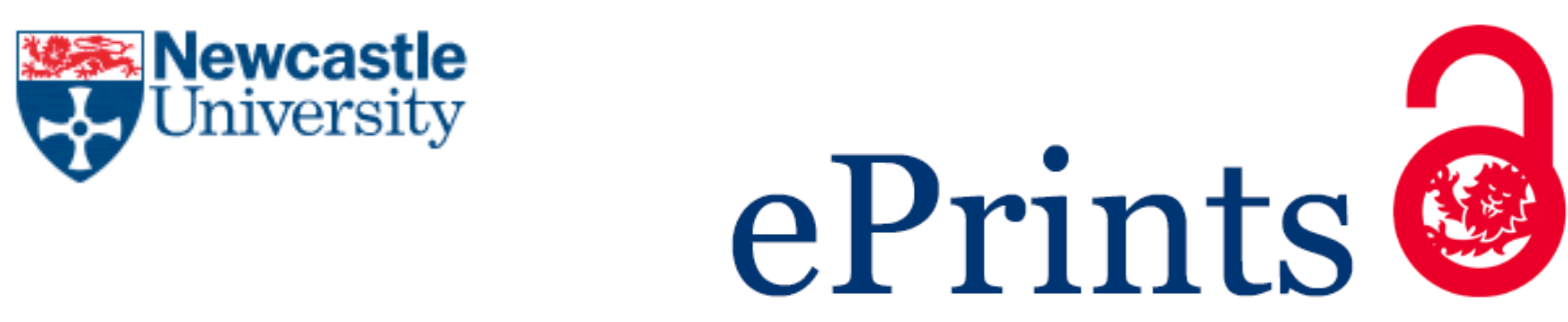

Munro I.

An interview with Snowden's lawyer Robert Tibbo on whistleblowing, mass surveillance and human rights activism. Organization 2017

DOI: https://doi.org/10.1177/1350508417726548

\title{
Copyright:
}

Copyright (C) 2017 (The Author). Reprinted by permission of SAGE Publications

DOI link to article:

https://doi.org/10.1177/1350508417726548

Date deposited:

$14 / 09 / 2017$

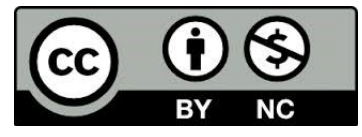

This work is licensed under a Creative Commons Attribution-NonCommercial 3.0 Unported License 


\section{An Interview with Snowden's Lawyer: Robert Tibbo on Whistleblowing, Mass Surveillance and Human Rights Activism.}

"... whistleblowing is a radicalising event - and by "radical" I don't mean "extreme", I mean in the traditional sense of radix, the root of the issue." (Edward Snowden)

Robert Tibbo is a prominent human rights lawyer and activist, and is the defence lawyer of the NSA whistleblower Edward Snowden. Snowden became Tibbo's client in 2013 as an asylum seeker in Hong Kong after he had fled the US as an NSA whistleblower, and revealed the existence of the US government's illegal programmes of global masssurveillance. In the following interview Mr Tibbo discusses the importance of whistleblowing for the functioning of democratic society, and the close relationship between whistleblowing and human rights activism. The interview addresses many important themes including i) the crucial role of whistleblowers as a check on abuses of power, ii) the apparent limitations of formal whistleblowing mechanisms, iii) the crucial role of supporters and helpers for the process of whistleblowing, that in Edward Snowden's case included journalists, lawyers, WikiLeaks and other asylum seekers, and iv) the illegal government surveillance of activists, protesters, and journalists. In his work with Edward Snowden the relationship between whistleblowing and human rights activism is made clear in its focus on the crucial role that whistleblowing can play in the protection of basic human rights such as the right to privacy and freedom of expression, as well as concerns over State retaliation not only against whistleblowers themselves but also against their helpers and supporters.

In the following interview Robert Tibbo makes frequent reference to the work of the UN Special Rapporteur on human rights (Scheinin, 2009). He notes that in many respects the UN Special Rapporteur had already raised many of the issues that were later revealed by Edward Snowden regarding the use of illegal mass surveillance by Western governments, and the use of secrecy by government organisations to avoid proper democratic accountability, as well as concerns about adequate oversight and whistleblowing mechanisms within intelligence organizations in order to prevent abuses of power. Some years before the Snowden revelations, the UN Special Rapporteur made the following prescient observation, "the Special Rapporteur is of the opinion that robust whistle-blower protection mechanisms for intelligence agents and other informers are crucial in order to 
break illegitimate rings of secrecy. Reliable factual information about serious human rights violations by an intelligence agency is most likely to come from within the agency itself. In these cases, the public interest in disclosure outweighs the public interest in nondisclosure. Such whistle-blowers should firstly be protected from legal reprisals and disciplinary action when disclosing unauthorized information." (Scheinin, 2009, p.22). In the following interview, Robert Tibbo explains not only the kinds of retaliation to which whistleblowers like Snowden are subjected, but also retaliation against the lawyers, journalists, activists and others who help these whistleblowers. In Snowden's case this retaliation has been especially apparent in the severe harassment that the asylum seekers who had helped him hide in Hong Kong have since been subjected to ${ }^{1}$.

Tibbo explains how the governments of the UK and the US have appealed to national security legislation to prevent whistleblowers like Edward Snowden from seeking legal redress in the courts where, "the hard part for these cases is that the government says 'No, I'm sorry, that's protected under this legislation - we can't disclose these documents we can't disclose what our activities are.' Your going in affected by this, you're going in with one hand tied behind your back - into a fight. And the government's saying to the courts, oh no, we can't disclose this, these are State secrets, you know by law we can't. So the court's hands are tied. ......" (Interview). Whistleblowers are thus unable to present evidence that could be used to support their case or to exonerate them. This is currently the case for Edward Snowden, but has also happened to a series of previous NSA whistleblowers including Thomas Drake and William Binney, who had attempted to go through official channels to blow the whistle on the programmes of mass surveillance, but had then been arrested and prosecuted under the Espionage Act. The courts themselves and the apparatus of the State may be turned against whistleblowers and their allies in a variety of ways, by means of surveillance targeted against them, police harassment, arbitrary detention, and the denial of asylum requests. The treatment of prior whistleblowers who had attempted to go through formal channels to raise their concerns is one of the reasons why Snowden chose to take a different route (see Heertsgaard, 2016).

The interview raises a series of important moral and political questions some of which have already been the subject of research in the area of organization studies and management studies, including about the process of whistleblowing in organisations

\footnotetext{
${ }^{1}$ See https://fortherefugees.com.
} 
(Contu, 2014; Dasguopta and Kesharwami, 2010; Miceli and Near, 2002; Munro, 2017; Near and Miceli, 1996; Vandekerckhove et al., 2016), about organisational surveillance (Ball, 2005; Bain and Taylor, 2000; Sewell and Wilkinson, 1992), and about the role of national security organisations and organisational secrecy (Costas and Grey, 2014; Grey, 2009; Munro 2016). Robert Tibbo's continuing work with Edward Snowden and his work in the field of human rights law provides unique insights into the ethical and pragmatic difficulties that whistleblowers and other activists face when confronting powerful institutions. In the following interview Tibbo discusses the need for adequate whistleblowing mechanisms and formal legal protections, but he also comments upon the apparent limitations of such mechanisms in effecting substantive institutional change. In this respect he describes whistleblowers as the "ultimate oversight". Of particular interest to researchers in the field of organisational ethics and critical management studies are fundamental concerns regarding: i) the close relationship between whistleblowing and human rights activism, ii) the use of new systems of global mass surveillance to target activists and journalists, iii) the use of secrecy by government organizations to avoid democratic accountability in cases of human rights violations, and iv) the effect of mass surveillance on freedom of expression, and problems relating to increased self-censorship and political apathy. These critical issues relating to whistleblowing and organisational secrecy have yet to be subject to in depth research in the field of the organisation studies and critical management studies, and it is hoped that the present interview with Robert Tibbo will provide a helpful introductory discussion of them from a key figure who has had first hand experience in confronting them.

\section{INTERVIEW WITH MR ROBERT TIBBO}

IM: Mr Tibbo, thanks very much for your time, it's a real honour to be sitting with you now. Your work [on Snowden, human rights and whistleblowing] is one of the most important things going on in the world right now. How did you get into it?

RT: Basically it came down to general human rights, you know, freedom of expression and then working with Mr Snowden. What it came down to... is that I was doing a lot of consulting and management consulting and doing a lot of due diligence work in Asia, and I saw how the human rights situation across Asia pacific... human rights violations... and I saw how there were inequities, a lack of distribution of wealth, and I just thought that I 
want to do something more grass roots. I went back to law school, and when I started practicing the law, you know, you realise that most of the people affected adversely by government policies, practices, legislation, are the poor, the marginalized, the vulnerable. The role of the Bar is to stand between the vulnerable individual and the government with its massive machinery. It was a matter of doing one case at a time. Really, those effected most by government failings, and abuses due to vested interests are the poor and vulnerable. So the leading cases [in human rights legislation] are fought at that level - with those that have nothing. Because if you're not fighting on that front line you're on a slippery slope and the next thing that will happen will be [representing] the lower middle class, middle class, upper...it's like a domino effect. Counsel knows that some of the best cases are for those with people who don't have any money, pro bono cases. I was fighting a lot of these kinds of cases and doing a lot of work for asylum seekers. Some of the asylum seekers were victims in the military, say in Sri Lanka, they were tracked down through government mass surveillance in the 2000s, a decade ago up to very recently. Even before Snowden's revelations came out I was aware that there were abuses by governments all over the world in terms of mass surveillance and targeting and tracking individuals, gathering private data. Hong Kong's a place where unfortunately too many [legal] counsel are focused on where the money is. That's not where my interests were. Of course, I need to make a living. When Ed [Snowden] showed up, you know, I had done a lot of work with asylum seekers who had been persecuted for... basically everything was fundamental to freedom of expression, religion, political opinion and those that may belong to a certain [marginalized] social group. So when Mr Snowden asked for help the first thing that was done was that we brought him to the UNHCR [United Nations High Commissioner for Refugees] to raise his asylum claims for refugee status. When I met Mr Snowden this was just another client, another case. I treated him no differently and proceeded with his asylum claims with the UNHCR. So that's pretty much how it started. Then working with Mr Snowden you come in contact with - in a very significant way - with fundamental rights and freedoms, such as freedom of expression, association, assembly, and this all comes back to how our lives, our private lives are affected, our personal lives, such as freedom of thought, conscience, and freedom of religion, mobility. How we practice our religion comes out of freedom of expression. What clothes we wear, where we pray, where we congregate, where we assemble. Working with Mr Snowden, you realise how significant his disclosures are, and the impact of government enacting greater security laws and how it effects people, and how people have modified their behaviour... Fear, people have a fear in expressing themselves. It [mass surveillance] has had what I call a constructive 
violation of people's fundamental rights, such as expression, assembly, association and religion. Snowden's revelations are the most significant for this century so far.

IM: You discussed this issue earlier today and yesterday [during a presentation], but what kind of difficulties have you faced in defending Snowden?

RT: Are you talking about the media or are you talking about in Hong Kong at the time?

IM: Both. Personal and professional difficulties...

RT: At the time, nobody knew. But after that ... a lot of friendships were lost, people just stopped contacting me, they wouldn't reply. A lot of people felt uncomfortable, they felt threatened, they felt that they didn't want to get into trouble by associating themselves with me. I've bumped into professionals in different professions and they have thought that what Mr Snowden did - even members of the legal profession, not just in Hong Kong but overseas - thinking that what Mr Snowden did was unforgivable, disgraceful. Some lawyers in different jurisdictions have called me disgraceful, saying "How dare you? Why would you do such a disgraceful thing in representing a man like Mr Snowden?" I politely asked them how long ago it was that they went to law school? Mr Snowden is entitled to legal advice. Whether I agreed with him or not, he is entitled to that legal advice and any protections that counsel can provide. And my view is that he didn't do anything wrong. There has been counsel in different jurisdictions who have advocated behnd my back to organisers of speaking events, advocating that the topic of Mr Snowden shouldn't be discussed [at events] - "You shouldn't be inviting Mr Tibbo to talk about this, it's disgraceful. It's not a proper thing for your organization to be holding this discussion [of Snowden's revelations]." Everybody is entitled to their opinion and that's fine, but as l've suggested to a number of people, if you disagree with Mr Snowden's views or you disagree with my views don't try to stop an organiser or a venue from allowing this debate to take place. Show up and express your own opinions. In one case an organizer asked this counsel - "You're invited to have this discussion and present your opinions, you can even have a debate with Mr Tibbo," and they declined. Mr Snowden's disclosures - I think they are necessary, it's created a lot of debate. There's been some polarization, some people feel strongly against him, others feel strongly for him. But what l've also found is that people don't have the full story. What Ed [Snowden] had disclosed is very complicated, and people have approached me asking if I'm Julian Assange's lawyer 
[laughter] and l've explained no, no, no. Mr Assange is a publisher and Mr Snowden is a whistleblower and I work for a whistleblower. I ask individuals what is Mr Snowden indicted on? They say, "Oh, treason, spying." I'm astonished. No, no, he hasn't been charged with any of these offences. He's been charged with theft, nothing more than that, under the Espionage Act. People are surprised. ... People are not clear on what Mr Snowden had done. They are not clear on the meaning of his disclosures, or the content of his disclosures. They are confused as to what he actually did and what criminal offences he is alleged to have committed. I'm a bit disturbed by that. Individuals should be scrutinizing the information they receive. I have spoken to some students who have asked me in the classroom [questions] assuming Mr Snowden has done certain wrongs, that his disclosures have caused people to be put in danger, and I asked them where did you get that information? "Oh, I heard that." So I said, I think you should read [about] this. I think the electronic mass surveillance and the operations that governments run, ex parte applications without full disclosure to courts, closed courts, has done more damage, more harm, torture, ill treatment, arbitrary detention, arbitrary arrest, and deaths of innocent people. More damage has been done behind... operations that are conducted behind closed doors, based on unreliable information collected through illegal electronic mass surveillance, shared with other governments. The damage has been significant. Most people are not aware of that, it's a lot of hard reading and you have to do your research. But I'm still a bit surprised when people think that what Chelsea Manning did and what Edward Snowden did caused harm or damage to people. Again, Mr Snowden, myself and other members of his legal team have pointed out - please show us the evidence of who's been hurt.

IM You mentioned earlier the important role of the media, but it's a double edged sword, because on the one hand they are misinforming, but on the other they are essential for your [democratic] mission on some level?

RT: It's not just the work I'm doing for certain clients, it's journalists' role in society in terms of government conduct... in criminal and legal conduct the role of the journalist is to report on this. They are a de facto oversight, basically a public oversight on operations to report to ensure that illegal and unlawful conduct is exposed, to ensure that there is the accountability and transparency that society demands and expects. The media stands in a crucial role to hold governments accountable. The fake news issues, journalists who are unethical, taking short cuts - there are no short cuts to being a good journalist - this has 
created more problems. It adds to the lack of transparency and accountability, this fake news. I've learned that, at the end of the day, if a journalist wants to talk with you, you've got to consider carefully who the journalist is, what their training is, their experience, and whether that's a journalist you want to talk to. I guess in a way it's like any other profession. I think there are some real problems today. Good journalists are going to do their research and they're going to get involved in the debate, and their going to ascertain the sources of their information.

IM: Can I ask about the role of WikiLeaks for example and the role of other whistleblower support groups like the Government Accountability Project in the US? Have you had any interaction with these people and these groups?

RT: Not with the US organisation. The interaction I had with WikiLeaks ... that was primarily during the 2013 period when WikiLeaks played a very important role in also assisting Mr Snowden in Hong Kong and assisting him when he got stuck in Moscow. But most of my work is in Hong Kong, it is concerned with the matters there and my clients who have an interest there.

IM: Do you have other NGOs or groups who support whistleblowing or support this kind of transparency project?

RT: This issue is important with the NGOs that I've worked with. For example, with Vision First $^{2}$, I was a director there for a number of years. We were demanding greater transparency for the Hong Kong government, the security bureau, the social welfare department and a Swiss organization, International Social Services ... how they were distributing assistance to asylum seekers in Hong Kong. Because there's a significant lack of transparency. And there's a lack of transparency on the International Social Services organization - there's a contract in providing assistance for rent. We've had a very difficult time holding the government and their contractors to account, and the government not providing sufficient assistance to asylum seekers, having asylum seekers living in dilapidated agricultural buildings, in land that's not zoned properly, landlords and middle men who are using incorrect addresses, food security issues. Again, all of this concerns

\footnotetext{
${ }^{2}$ Vision First is a human rights NGO that supports rights for refugees.
} 
government in Hong Kong where there's been a lack of transparency. So from 2013 to 2016 we did a lot of work in this area demanding this transparency.

IM: You talked about apathy a bit yesterday, but this is a good example of activism in society - these transparency projects and NGOs?

RT: Yes. In a place like Hong Kong, and not just Hong Kong, but in other jurisdictions, there's this apathy that has set in. We're all too busy, we're trying to make money, we're trying to survive and things aren't too bad. But the fact is that transparency and accountability are crucial to maintaining the rule of law and to prevent government abuse, because government will abuse if they are given the opportunity. History has shown that is going to happen time and time and time again. Go back to your question on that again?

IM: The basic question is what kinds of NGOs and other groups are useful in this kind of work?

RT: The Hong Kong Helpers Campaign did a great job as well exposing the egregious conduct of interested parties over foreign domestic helpers in Hong Kong. One of the significant cases is the Erwiana [Sulistyaningsih] case, an Indonesian domestic helper who was tortured in Hong Kong by her employers and how the Labour Department failed to act, the licensed labour agencies failed to act when Erwiana tried to escape. The failure to provide state protection, again the Hong Kong Helpers Campaign - Tom Grundy was the founder and I was the legal adviser ... at a grass root level ... [and] what is happening in local communities. There's a lack of transparency, a lack of accountability. One of the more significant problems in Hong Kong today at a much higher level is [where] Amnesty International has put forward questions to the Hong Kong government since 2014 and has asked to meet with the Hong Kong government to speak with them since 2014 but the Hong Kong government refuses to speak with them or answer questions.... Amnesty International released a report in early January about the Hong Kong government's refusal to meet, discuss, disseminate information ${ }^{3}$. There's a complete lack of transparency today and accountability of the Hong Kong government with international NGOs. I have had interactions with Amnesty International and Human Rights Watch of recent specifically on these issues in Hong Kong. The other issue is that there's a UN committee against torture,

\footnotetext{
${ }^{3}$ See "Amnesty International Report 2016/17: The State of the World's Human Rights," https://www.amnesty.org/en/documents/pol10/4800/2017/en/
} 
the 5th periodical report, a preliminary publication in December 2015 where the Hong Kong government is heavily criticised for its screening mechanism and lack of rule of law, the treatment of asylum seekers, but also the abuses by police in Hong Kong ${ }^{4}$. Mainland China is the counterpart to the UN Committee against torture that has to provide a reply to those criticisms, and that reply by law had to be submitted in December 2016 or January [2017], but mainland China has failed to reply as is required by the UN convention against torture. Again, this is another example of the mainland Chinese government and the Hong Kong government refusing to comply with their international legal obligations and a complete lack of transparency and accountability.

IM: and you're dealing with these kinds of issues as a human rights lawyer on a daily basis?

RT: Absolutely. There's another issue in addition to the lack of transparency and accountability. For the screening mechanism in Hong Kong, there's a completely closed system, it violates Article 10 of the Hong Kong Bill of Rights and Article 16, which is freedom of expression. Freedom of expression is not just ones right to freely express yourself [interruption ....... N. None of the decisions on asylum seekers are published for the public, there's this completely closed system, and the acceptance rate of asylum seekers is zero - 72 cases [accepted] out of 30,000 since 1992.

IM: So why did Edward Snowden choose Hong Kong then? It's seem a little strange....

RT: The reaction I get from most people when I just meet them and I say what do you think of Hong Kong, they have this very positive image of a free place - a very shiny, wealthy, safe place. But the reality is very, very different. When Mr Snowden received legal advice, when he saw the reality, when he was put in a position where he was fully informed, he had to make a decision on whether he really wanted to be in Hong Kong or not. And in the end he decided that it was in his interests to go elsewhere. [....] People are shocked. The three lawyers whom I am working with who have filed asylum applications for the families who have helped Mr Snowden, [applications] into Canada, they visited Hong Kong on a fact finding mission, they've seen this reality and they have exposed this reality publicly.

\footnotetext{
${ }^{4}$ See "Concluding observations on the fifth periodic report of China with respect to the Hong Kong Special Administrative Region," UN Committee Against Torture, http://www.vfnow.org/wpcontent/uploads/2015/12/UN-Committee-against-Torture-recommendations-Dec2015.pdf
} 
There have been court cases in Hong Kong by politicians and people who have standing, who want information on government decisions that have affected the population, that have affected groups, and the Hong Kong government has not been forthcoming on these disclosures. In Hong Kong there's not a full democracy, you can't elect people out of office who are in the executive. The government has been emboldened so that they can project their power and influence without really considering the rights and interests and needs of individuals in Hong Kong. So really you have the role of the media and the role of lawyers that continue to fight for universal suffrage, but also greater transparency and accountability of government. You have people who have been renditioned out of Hong Kong, where the Hong Kong government has not been forthcoming on that information.

IM: They don't even know who has been kidnapped?

RT: We know. It's book sellers ${ }^{5}$, it's Xiao Jianhua, a billionaire in January taken from the Four Seasons hotel, a Canadian hotel in Hong Kong. There's been a lack of accountability of Beijing, the Hong Kong government hasn't disclosed really anything on what happened. They haven't held Beijing to account. We don't know what's really going on.

IM: and you're having some issues with your clients, the refugees who helped Snowden based on similar related stuff.

RT: Correct.

[The discussion moves to the work of the UN Special Rapporteur on Human Rights and Counter Terrorism]

IM: I take it that this guy [the UN Special Rapporteur] didn't have a detailed idea of the [surveillance] systems? That only came out with Snowden.

RT: No he didn't. But he knew what was in the box... inside the box. He relies on a lot of cases where information was illegally gathered - it was not reliable information - it was shared with the US government. The government arrested people arbitrarily. In this one [UN report] they are talking about interrogating, renditioning... they're talking about all the

\footnotetext{
${ }^{5}$ The book sellers, Minhai, Lui Por, Cheung Chi-ping, Lee Po and Lam Wing-kee have all been renditioned to mainland China.
} 
human rights violations in counter-terrorism....this is what l've been talking about since February 2009.

IM: Do you use this stuff in your practice as well?

RT: Absolutely... I've had commercial cases where one of my clients had the opportunity to whistle-blow. I have even had a high court judge discussing it with me. I didn't even raise it at that point.

IM: What is a "right to a remedy"?

RT: Let me see. In the ICCPR [International Covenant on Civil and Political Rights] and usually in any bill of rights there's a provision that the courts - the constitutional courts they have powers to provide remedies to those people who have been... you know, whose fundamental rights and freedoms have been violated ${ }^{6}$. What they're saying here is... okay... human rights are [mumbled reading of text of UN report] So let me just give you an example. Go to the Hong Kong Bill of Rights. And you'll see this in any international instrument, and in any country that has a constitutional instrument.

IM: I remember Bush and Cheney had this "illegal non-combatant" thing which tried to get around the idea of the...

RT: ... Geneva Convention, the protection of soldiers.

IM: Yes.

RT: Yes. But they did it offshore, not in the United States. It was military jurisdiction. It was just a mess, and the higher courts were against it... but then they were for it.

IM: ... trying to exempt people from the law somehow?

\footnotetext{
${ }^{6}$ Article 8 of the Universal Declaration of Human Rights states that, "Everyone has the right to an effective remedy by the competent national tribunals for acts violating the fundamental rights granted him by the constitution or by law."
} 
RT: Now what they're saying is that remedies are not just after somebody's been hurt. It says that human rights obligation of states - so that would be anyone who signed the IPCCR - included the obligation for an effective remedy... requires that such legal provisions must not lead to a priori dismissal of investigations or prevent the disclosure of wrong doing. So under Article 6 of the Hong Kong Bill of Rights and you'll see under the IPCCR, the Canadian Charter, the New Zealand Bill of Rights...you'll have this provision where the courts have this power. And they're saying it's not just after the fact and we're in court. There have to be remedies before that. So the problem here is, as you know in the US and the UK is that the government has argued that there shouldn't be full disclosure of everything. And if there's not full disclosure there's no investigation. Then the person who's affected can't go to court. And that may be a person or may be a group of people who are affected. And you have no remedy. You have no grounds to go to court, or you don't have the evidence, and then you go before the court and the court says look we can't do anything - we don't have the full picture.

IM: You mentioned yesterday that Snowden is not allowed to use the free of expression [law] - one of the whistleblower protections ...

RT: Yes, that's right.

IM: They just say that you can't use that law or information and then they can't defend themselves?

RT: You can't. So this is really crucial right here. So basically what it's [the report of the UN Special Rapporteur] saying is that the government can't come in and say look we can't disclose anything because that prevents an individual or an interested party to go into the courts and say hey look there's something wrong going on here. So Ed [Snowden] would not have been able to disclose any of that stuff, for example. So this whole [UN] paper is about how the government of the United States for example, or we could go to the UK - is discussing how the nondisclosure is allowing human rights violations to continue. And the courts can't do anything, because you can't show this [evidence] to the court. If you don't have the evidence you would not even get leave to go to the court to argue this. So if you look into "Citizen 4" the case concerning wire tapping [global mass surveillance], the US government said that the courts shouldn't be allowed to decide on this or to review what the administrators are doing. So you understand that in administrative law it is the 
executive branch that are making decisions and doing things, and you can scrutinise that by going to a high court judge and saying hey look, they are violating certain human rights legislation, or violating an individual's rights, please intervene, stop them from doing that. So the US government argued in Citizen 4 that no, no, no - you [the court] don't have the right to review this case [because] this is all confidential information. Which is extraordinary. The judges were saying - we don't have the right to review this... but they did of course [eventually]...

IM: But after Snowden - the congressional review where they decided there wasn't enough oversight...

\section{RT: Right.}

IM: ... But the [recent] CIA stuff suggests that it's all still going on...

RT: It's a bit convoluted. What it [the UN report] is saying is look you can't hide this stuff from the courts - the court's role as a check and balance on the executive and executive powers. And the courts have the power to provide remedies to somebody's who's been hurt, whose rights have been violated. So they're [UN] saying that look the remedies are illusory. This is just window dressing, if there's non-disclosure of what's going on and what's going on include human rights violations. [Mr Tibbo directs IM to a section of the UN report on whistleblowing and human rights]. This report is early 2007-2009, so Obama knew about this. This was put in front of the General Assembly. It was put in everybody's face.

IM: This is extremely interesting - I will go away and study that [report] ${ }^{7}$. So how do they get away with ignoring that - these kinds of laws, these kinds of reviews?

RT: Nobody complains. Nobody knows. And these cases take sometimes 5 years or 10 years to work through the court system. So the problem is - I think I mentioned yesterday [...] is that you can only do so much as a lawyer through the courts. And these cases take years because you ask for full disclosure from the other side, relevant disclosure, and the other side does not disclose it - the government does not want to show everything. And

${ }^{7}$ See Scheinin (2009) 
then the hard part for these cases is that the government says, 'No, I'm sorry, that's protected under this legislation - we can't disclose these documents - we can't disclose what our activities are.' Your going in affected by this, you're going in with one hand tied behind your back - into a fight. And the government's saying to the courts, oh no, we can't disclose this, these are State secrets, you know by law we can't. So the court's hands are tied. ... so that's what the previous paragraph was saying [indicates UN report] - you're tying the hands of the courts. You're saying you can't disclose everything so that people who have been affected, people who are standing can't seek remedies from the courts. and even if they try, because they don't have all the information the courts are stuck. Because they're like - look we've only got half the picture here. So the whole system grinds down to a halt. But the government is able to move forward with impunity. There's no transparency, no accountability. Then [the UN Special Rapporteur] talks about journalism. So the NGOs, the media,Glenn Greenwald, Laura Poitras, even people like William Binney and Ed [Snowden]- these are the people saying look, the public's got to see this. If we keep going through the courts we're never going to see this. We're never going to know what's really happening. ... So that's why they say the most reliable intelligence is going to come from people within the agency itself - somebody deep inside. But you'll never get somebody like that going to court because they'll be arrested right away. They'll be stopped. They'll say you can't do it.

IM: Which is what happened for a lot of these guys [NSA whistleblowers such as William Binney, Thomas Drake and others]

RT: Yes, exactly. And sometimes the disclosures were innocent, just through negligence and then they get nailed. So there was no way for Ed [Snowden] to go through any channel, because they were going to get him. If you come from the outside... you can't get this information... Then there's the role of the journalists. [...] it's so important to have lawyers and journalists.

IM: One thing I find interesting is WikiLeaks, with Alan Rusbridger and Ewan MacAskill [from the Guardian] were brilliant in the early days with WikiLeaks but there's been a big falling out over the last few years ... the same with the New York Times and so on [...]

RT: The journalists are really an unofficial external control mechanism. You can't remove these people from the US government [....] You can't remove them. In a way the NSA, the 
CIA ... what they've been doing - government mass surveillance - they're entrenched, they can't get out. You can't pull these people out of there. They've been there long term, they know they've committed crimes. The whole thing is undemocratic. Previous presidents and administrations have said, yes, keep this thing going, so new administrations come and go, come and go. So you can't get these people out of there. The journalists can see the surface. Somebody upstanding can go to court, but then it's stopped in court. So what do you do? Find somebody from the inside, right?

IM: It's interesting that Clapper [former Director of National Intelligence] lied to Congress, and is on TV lying to Congress, but there's still no comeback and he's still in charge ${ }^{8}$.

RT [RT Laughter] There's no consequences to him. Okay I talked about this with Ed [Snowden] and Ed's talked about this publicly. One of the problems here is that the people inside... so you've got your democratic judiciary, executive, legislature, right? So you can remove most of these people, but not the judiciary, and you hope that the judiciary is independent, but then you've got these institutions [intelligence agencies] with people who have worked there 10, 20, 30 years. They've broken laws for 10, 20, 30 years. You point out to them, you've broken the law. These people have mortgages, they have families, they have their reputations, they have their pensions coming. They're all criminals right? So when you go to them and say, look, you've done wrong, what is their reaction going to be? You know you're right - let's expose all of this [IM laughter] ... so the problem here is that they're going to fight to protect themselves because they know they've been caught out. So you have these institutions that have been there for 20, 30 years that are full of cancer, once the cancer's in there you're never going to get it out. Even the "doctors" say oh yeah, we did the tests and you're cancer free, but that's crap, the cancer is hiding someplace in your body. And maybe it doesn't come back for 10, 20 years, but maybe it comes back with a vengeance. But you can't even get the cancer out of these institutions because they're entrenched. You just can't get it out. Ed [Snowden] talked about that quite a bit. Even if you have the whistleblower mechanisms - and the United States hasn't put in what Schienin [Martin Scheinin, UN Special Rapporteur] has recommended. Let's say they put it in, and there's somebody coming through here, the first thing is would that person be able to get through to the independent mechanism, or would something happen to them? For example would they be arrested under the Espionage Act [which has already

\footnotetext{
${ }^{8}$ In fact, James Clapper resigned from being Director of National Intelligence in 2016, effective from January 2017.
} 
happened to several NSA whistleblowers]? Would they disappear and be renditioned? Or would they die in a car accident? There's a high propensity for employees in the US institutions to protect their terrain. They're like, "I'll wait 5, 10 years, in 20 years l'll pass away and give the money to my kids." So even if you put in a whistleblowing mechanism now, I have my doubts that it is going to be very effective. I think everybody is going to be watching each other because this has gone on for too long. It's gone too far.

IM: So it does require some bigger activist commitment or social commitment somehow?

RT: I think what needs to happen is an administration needs to come in and say, "Everybody out! You've got to go."

IM: Really? Why?

RT: Because you have people with 20,30 years in these institutions, they know they've broken the law, they don't want to get blamed, they don't want to be subject to a complaint in a whistleblower mechanism. So I think an administration would have to come in and say "Everybody's out. We're cleaning house." Now what did Trump do? He fired... how many prosecutors did he fire? So he wanted to clean house. I don't know if he was right to do that, but for some reason Trump wanted the prosecutors out. In my view the government mass surveillance, the programmes that are in place, an administration has to come in and clean house and put in an oversight mechanism, a whistleblower mechanism to protect... I think both things have to happen. The other things I believe that you need whistleblowers because they are the ultimate oversight. But I think that by just saying, okay, let's put in the mechanism now, it's ummm....

IM: There's almost a critical mass of whistleblowers, it seems to me because Snowden was the first one other than Manning, that I started getting interested in and then I discovered that there's a whole slew of these guys who have been prosecuted but who are now speaking out and I think that's interesting. So Ray McGovern has founded a "Veteran Intelligence Professionals for Sanity" and it's a bunch of CIA, NSA retired guys [and whistleblowers] who have all got together and they give regular commentary on official releases. I think that's quite an interesting development. It's different from the whistleblowing but it's a positive... 
RT: It's a positive thing, but there has to be this change. With what Snowden did it's quite clear that there has to be change. There's going to be this conflict, like a tug of war where those who are entrenched are going to pull this way and those who are saying look, the disclosures are made, it's got to go this way. Scheinen [UN Special Rapporteur] is saying that at the end of the day you've got to let the courts look at this - I agree. And typically what happens is that under Article, I think it's Article 17 [mumbles I'll have to go to the ICCPR], there's one provision on open justice. You have to have justice to be done, but also to be seen [to be done]. So you need the judges as final arbiters. In the way that's been handled in most of the commonwealth law is that if there's a hearing and there are state secrets involved it has to be a closed hearing. If a judgement's going to be handed down you redact... you just don't mention certain parts of it, and as lawyers we do that all the time. In the common-law world there's something called the [unclear word] procedure. It's a British case where somebody who's caught for a serous crime, let's say drug trafficking... terrorism, and you've got that person, you've got the evidence on that person, and that person is going to go to prison, that person can say, I can help you, I'm going to work with the police, I'm going to work with the prosecutors, and I am going to provide intelligence to you and information. So in effect this person becomes a whistleblower to, say organised crime. This person isn't sent out into the field. This person just provides intelligence, and then would be willing to testify against, let's say these people who are the masterminds. In these criminal proceedings we go on camera, which means the doors are shut, it's in chambers, closed to the public. Even the judges say, "we're adjourning the matter", so everybody leaves the public area, doors are closed and then we start again. It's quicker. We're not allowed to talk about this outside the court room. Nothing will ever be published. And then we explain to the court, this is what my client did, we helped the police do this and that, this is going to go to trial, he's going to testify. So I did a drug trafficking case once, [where] a woman got caught with methamphetamine hydrochloride - "ice". She's looking at a three years prison sentence. But she helped the police. So I go into the courtroom on her sentencing date and the courtroom's emptied out. So I do full mitigation. Then the court's closed, opened up again, everybody comes in. There's about 15 other barristers there, every barrister knows "Rob you're client's getting 3 years". And the court says without mentioning anything about the previous mitigation in private, in chambers closed to the public, "I've considered all the mitigation and I will reduce her sentence by two-thirds" - she gets a one year sentence. And I remember everybody looking at me like "what?" 
IM: How did you do that?

RT: I had a good magistrate. I had a good judge. Scheinin's saying the same thing - at the end of the day you redact... and there should be a minimum intrusion on two things: freedom of expression and open justice. Freedom of expression is not just expressing yourself, your writing as a journalist or as an academic, it's also the right to receive that expression, and to record that. So it goes both ways. The justice system demands that it must all be open justice, it should not be closed at all, but to protect State secrets, to protect individuals who...

IM: But that's what they are arguing is it not?

RT: But the judges should be allowed to see it all.

IM: Right. I see.

RT: They should see it all. The other party should see it all. Okay? It's simple. You tell the lawyers - at the end of the day it will only be the lawyers in there. You tell the lawyers you can't disclose this. You disclose this and you're in contempt [of court]. And more seriously, if you disclose state secrets then you're going to get nailed, let's say under the Espionage Act.

IM: So at the moment, the courts can't see any of it and they can't make a judgement on it. There's no oversight on these cases.

RT: The FISA court [United States Foreign Intelligence Surveillance Court] doesn't even let the opponent go in. The FISA court is all ex parte. It's only the government going in saying, "I want a warrant". Then the judge says, "Can I see the evidence?" and then they say, "No, no, under the [anti-terrorism] legislation you can't see anything. We'll just represent to you."

IM: That's crazy.

RT: It is crazy. In ex parte applications where only one side goes in, counsel have an obligation to full and frank disclosure, which means that you can't hide anything from that 
judge because that judge is making a decision where the other party is prevented from making representation. So that's a denial of natural justice to the party that is going to be affected. That's what's happening in the United States. They [government lawyers] were going in saying that you can't see any of this, or they see only half of it and say "We want the warrant." The judges stamp it.

IM: Everything gets rubber stamped basically?

RT: It was all rubber stamped in the end, with so much being hidden. You have seen the same thing with CSEC in Canada ${ }^{9}$. There's an oversight committee for CSEC, a former federal court judge was in charge of it. And CSEC, which is the equivalent of the NSA, they were hiding everything form these oversight judges. They were lying. So what happened? The Canadian CSEC, they were spying on the Brazilians, not for counterterrorism, or to protect people, they were spying... it was industrial espionage. The Canadian CSEC was getting intelligence on government and mining companies, feeding it to the Canadian government, feeding it at the end of the day to the Canadian mining companies so that they would have an advantage in bidding for projects.

IM: It's like Merkel ${ }^{10}$ was being spied on for the same... during European trade negotiations. The same sort of thing.

RT: Yes. The same thing. So here you have an improper purpose. If you go to CSEC... [refers to websites]

IM: Also, all these social movements get spied on... Greenpeace, everybody, all the protesters...

RT: Yes, all the NGOs, political activists, Greenpeace, indigenous communities, First Nations people.

IM: Did this this come out from Snowden as well?

RT: Yes. Snowden and Greenwald brought it out through Snowden.

\footnotetext{
${ }^{9}$ Communications Security Establishment Canada.
}

${ }^{10}$ Angela Merkel is the Chancellor of Germany. 
IM: And Canada is one of the Five Eyes as well?

RT: Yes, that's right.

IM: So, it's all very cosy.

RT: I've made a few [legal] statements on this. Nothing's been published. I can send them to you if you want to look at them?[...] Do you know that the EU passed a number of resolutions on whistleblowing ${ }^{11}$ ? I was asked to comment on that a couple of years ago. I recommend that you may want to look at those resolutions. There was one report in 2013 that was very comprehensive and there was another one in 2014.

[Interruption]

RT: It's dangerous stuff. It's really dangerous stuff. One thing that concerns me is that at the end of the day this is big data, this is data that governments can use to profile you, to decide to target you, to follow you, track you, when you're completely innocent. My other concern is data that's been modified, or data that's incomplete and ambiguous and governments act on it and you're arrested, you're detained, and there's a number of cases in the Scheinin report [where] he talks about a Canadian who just suffered horrifically. I'll show you that case in a second. I went to London in 2013 in September and I was concerned because Glenn Greenwald and his partner had been detained.So I was concerned that the British government was going to give me a hard time.

IM: That was going to be one of my other questions - harassment - because you talked about targeting your clients [asylum seekers in Hong Kong], but you didn't really talk so much about whether the intelligence services were harassing you or the state was harassing you.

RT: Well, when I flew into London that time I didn't have my computer with me, or cell phone.

\footnotetext{
${ }^{11}$ See "Protection of Whistleblowers: A Brief Guide for Implementing a National Framework", Council of Europe, 2016, https://edoc.coe.int/en/fundamental-freedoms/7053-protection-ofwhistleblowers-a-brief-guide-for-implementing-a-national-framework.htm
} 
IM: There's not much they can do then...

RT: No. I had no data. I made sure of that. But I wasn't harassed. But I think with a lawyer, the US government, the British government, the Canadian government, they're not going to do anything that's overt. They're going to do something that's covert.

IM: So you just don't know?

RT: I do know. All I'll say is that some things have happened. I do know. They have an interest in looking at what l'm doing. But that's something for later disclosures. But they've done nothing overt. It's been covert, and it's to be expected. For example the Hong Kong government questioned my clients- the three refugee families, the adults, about $\mathrm{Mr}$ Snowden. They didn't come to me. They're trying to pick on vulnerable people, who were smart enough to say, "No. Talk to Mr Tibbo." And you have the Sri Lankan police, the criminal investigation division harassing the families, going to the extended families in Sri Lanka and saying that, "Hey, we want to know what's going on, where your children are, or [where] your brother is in Hong Kong. We want to know their address, telephone number, and their friends." Then the Sri Lankan police show up in Hong Kong and try to target my clients. There seems to be - for almost any country - if they can get data on Mr Snowden, there's this security interest. So my clients know not to say anything. They [the refugee's who helped Edward Snowden] respect Mr Snowden's privacy.

IM: It must be a very, very difficult position for them.

RT: But I don't think the US government or any government wants to be interfering with a lawyer in their legal practice. Not overtly anyway. I think it was "Meet the Press" - you'll have to check this - in 2013 - I think one of the moderators said to Greenwald, "You should be arrested for treason." ${ }^{12}$ And there was a very big backlash from the American public saying, "Hey, that's going too far." Journalists need to be protected, they should be allowed to do their job, and lawyers should be allowed to do their job.

\footnotetext{
${ }^{12}$ A number of media commentators and politicians had called for the prosecution of Greenwald, e.g. see http://www.huffingtonpost.com/2013/06/24/glenn-greenwald-meet-thepress_n_3491290.html
} 
IM: And the New York Times would be next... it's just a ridiculous idea.

RT: Yes it is.

IM: It's amazing what people are happy to say, politicians and various commentators...the threats that they have made over the past years

RT: You have to look into what can be done to protect privacy, but I was thinking there are bigger issues about, you know, are governments able to spy? If there's a request to see what's in a [computer] cloud, to see what's in some database, is that going to be made public or is there going to be some shield on it where the public's never going to know? And what are the repercussions of when the government does disclose it? Have the government put into place legislative provisions that are going to punish somebody who says, "Hey look, there governments are actually going to clouds and grabbing data." The academics were looking at the minutiae, the fine details of what legislation do we need to protect data, but they weren't looking at what governments can do to intervene to see the data, to grab the data. What can a civilian do to prevent that from happening? I thought that there are too many problems here. There's a lack of transparency. Do we really know what governments are doing? And the US government made it clear that they were breaking the law. The Canadian government - CSEC - they were breaking the law. So do we really know what's going on? [....] You also know from Snowden's disclosures that the US would not be allowed to spy on US civilians?

IM: Yes, unless it's communicated with someone outside the US...

RT: Right. But then Snowden revealed that the British can spy on the US civilians, or the Canadians, and will they share that information with the US [laughter]? And Snowden also revealed yes, they're sharing that information.

IM: What's your opinion of current whistleblower protection laws?

RT: I'm aware that in certain jurisdictions there have been whistleblower protection laws, being enacted in commercial areas, for example related to public companies, information related to the stock exchange, publicly listed companies' behaviour, so more on the 
commercial side ${ }^{13}$. We're seeing some of this happening. But on the government side, so far as I am aware the US government hasn't really put into place the whistleblower mechanisms that have been advized, For example see the UN Special Rapporteur on Human Rights and Counter Terrorism, the past and current UN Rapporteurs - there seems to be much slower progress on that front.

IM: As academics or concerned citizens, can you recommend activities - what would you recommend we do?

RT: In full democracies it's really up to individuals to... and this is what Mr Snowden has advocated - look here are the disclosures, these are the issues, they need to be discussed. They need to be openly debated, debated robustly and vigorously. People have to get involved. People should be communicating to fellow members in their communities. They should be writing to their locally elected politicians, to their members of parliament who've been elected and raising their concerns about the issues that Mr Snowden raised. That is, there needs to be oversight, there needs to be accountability and transparency. This needs to be done to protect the individual's fundamental rights and freedoms. For individuals to say, "I've got nothing to hide. I don't mind of the government is checking on me." That's naive and utter nonsense. If they really feel that way, why don't they install cameras in their houses, in their bedrooms, in their washrooms, put cameras in their cars and have a camera on all the time? If they feel comfortable doing that, then that's fine, but that's effectively what governments are doing. And unfortunately large corporations are cooperating with that - some of the big internet companies have complied with requests. Cell phone manufacturers - the batteries can't be taken out of their phones... governments have the ability to spy, look at your email, look at the internet sites that you go to, to activate the speaker on your cell phone, to turn it into a microphone, to record what you're doing, to track where you're going. I have done a criminal case, an extradition case a few years ago, where the law enforcement was using electronic mass surveillance to track the cell phone of a client. Then they were using that as evidence against the client. Last year Mr Snowden spoke at McGill University and by coincidence, a couple of days before he spoke, it turned out that a Quebec magistrate had issued multiple wire taps that allowed Quebec provincial police to track the cell phone of a press journalist. That journalist had

\footnotetext{
${ }^{13}$ For example, section 806 of the Sarbanes Oxley Act, 2002 has provisions for whistleblower protections, as does Section 922 of the Dodd-Frank Wall Street Reform and Consumer Protection Act, 2010.
} 
done nothing wrong. He was talking to police officers inside the police force in Quebec who were acting as whistleblowers [about police corruption]. So the first problem here is that the magistrate should never have issued the wire tap on a journalist because there was no [legal] basis to track his phone. What should have been done is that the police should have found another route to investigate the matter, if they were investigating other police officers, not to interfere with the journalist ${ }^{14}$. That was a clear violation of the journalists' privacy rights. [...]

IM: Was there any come back for the magistrate?

RT: Oh my god, there's an ongoing investigation. When it was discovered, it was like a domino effect. This is no different from what the US government was doing. It turned out that other journalists had been hit. The problem with what the magistrate did with the Quebec police is that the sources are all whistleblowers in Quebec. If whistleblowers know that there are warrants being issued [against] privacy rights and the right not to be spied on [then] whistleblowers will never talk to the journalists. This was a strike at the heart of the rule of law, and the role of journalists. Now there's a commission of inquiry.

IM: So there are ongoing threats to basic democratic freedoms?

RT: Absolutely.

IM: What kind of values and ethics motivate your work?

RT: That's a good question. Growing up as a Canadian, the way I was raised... you know that fundamental to a healthy democracy is that everyone is given an equal opportunity, an equal chance, and unfortunately in most of the world people are looking for advantages... advantages over other people. Unfortunately, to gain... quite often to cause detriment to others. Living in the Asia Pacific I asked myself ... in some rural areas in mainland China, South East Asia, what if I was born into that environment? Would I be able to arrive where I am today? Each time I ask myself that I say, no, I would not make it here. A big part of the reason why I am here today is because of where I was born. I was born in a place where there was rule of law, where every child is given an equal opportunity for the most

14 The Canadian journalist Patrick Lagacé. 
part to receive an education and to be on a track for their own personal, human development. l'd got to a point where l'd seen a lot of immoral, unethical, illegal behaviour in Asia Pacific, not just Asia Pacific but all over the world, and I thought I want to participate at a grass roots level, and hopefully work on cases where you're able to participate, to defend against injustices, or to advocate against injustices. The fundamental rule of law is to ensure that people are all playing by the same rules... governments [should] not abuse their position, but there's a propensity for government to do that. I think the bottom line is that l'm participating with a view and a hope that l'll be able to contribute to a more equitable society, where people don't act in conflicts of interest of others, and people in fiduciary positions act in the best interests of those who rely on their support and are vulnerable. [....] Really, l've gone into law because I want to participate in and contribute to the conscience of society, so that people are give a fair go.

IM: I think all the questions are covered. I'm extremely grateful for your time and I want to say again, it's been a great honour - thanks.

RT: Thanks for reaching out - keep in touch. Whatever you write l'd love to read it. Okay we're done.

\section{References}

Bain, P. and P. Taylor (2000) ‘Entrapped by the electronic Panopticon'? Worker resistance in the call centre. New Technology, Work and Employment, 15(1): 2-18.

Ball, K. (2005). Organization, surveillance and the body: towards a politics of resistance. Organization, 12(1) pp. 89-108.

Contu A (2014) Rationality and relationality in the process of whistleblowing: Recasting whistle- blowing through readings of Antigone. Journal of Management Inquiry 23(4): 393406.

Costas, J. and Grey, C. (2014) Bringing Secrecy into the Open: Towards a Theorization of the Social Processes of Organizational Secrecy, Organization Studies, 35(10): 1423-1447 Dasguopta S and Kesharwami A (2010) Whistleblowing: A survey of the literature. The IUP Journal of Corporate Governance 9(4): 57-70.

Grey, C. (2009) Security Studies and Organization Studies: Parallels and Possibilities, Organization, 16(2): 303-316 
Hertsgaard, M. (2016) Bravehearts: Whistle Blowing in the Age of Snowden, Hot Books, New York

Miceli M and Near J (2002) What makes whistle-blowers effective? Three field studies. Human Relations 55(4): 455-479.

Munro I (2016) Organizational resistance as a vector of deterritorialization: The case of WikiLeaks and secrecy havens. Organization 23(4): 567-587.

Munro, I (2017) Whistle-blowing and the politics of truth: Mobilizing 'truth games' in the WikiLeaks case, Human Relations, 70(5): 519-543

Near J and Miceli M (1996) Whistle-blowing: Myth and reality. Journal of Management 22(3): 507-526.

Scheinin, M. (2009) "Report of the Special Rapporteur on the promotion and protection of human rights and fundamental freedoms while countering terrorism", United Nations, http://www.refworld.org/docid/4bbee46a2.html

Sewell, G. and Wilkinson, B. (1992) 'Someone to Watch Over Me': Surveillance, Discipline and the Just-in-Time Labour Process, Sociology, 26(2) 271-289

Vandekerckhove, W., Fotaki, M., Kenny, K. Humantito, I., Kaya, D. (2016) Effective speakup arrangements for whistle-blowers: A multi-case study on the role of responsiveness, trust and culture, The Association of Chartered Certified Accountants 